\title{
Brexit and the Overseas Territories: Repercussions for the Periphery
}

\author{
PETER CLEGG* \\ Senior Lecturer in Politics, University of the West of England, Bristol
}

\begin{abstract}
There are 14 United Kingdom Overseas Territories (UKOTs), of which nine are associated with the European Union (EU) via the Overseas Association Decision (OAD) adopted by the EU in 2013. Gibraltar, meanwhile, is part of the EU under Article 355(3) of the Treaty on the Functioning of the EU. Only the citizens of Gibraltar were able to vote in the referendum on the United Kingdom's (UK) membership of the EU, but the consequences for all are potentially very significant. The UKOTs benefit currently from economic and environmental cooperation, as well as development assistance and policy dialogue. The article considers briefly the growth of the relationship between the UKOTs and the EU, before setting out the key aspects of the relationship which the Territories are keen to maintain. The second half of the article focuses on the (minor) role the UKOTs played in the referendum debate, and what might happen to the present levels of cooperation as the UK disengages from the EU.
\end{abstract}

KEY WORDS: Brexit; Overseas Territories; European Union; trade; development assistance; security

\section{Introduction}

There are 14 United Kingdom Overseas Territories (UKOTs) spread across the globe, of which nine are directly associated with the European Union (EU) via the Overseas Association Decision (OAD) adopted by the EU in 2013. These are Anguilla, Bermuda, British Virgin Islands (BVI), Cayman Islands, Falkland Islands, Montserrat, Pitcairn, St Helena and Turks and Caicos Islands. Ascension and Tristan da Cunha fall under St Helena in the OAD. Gibraltar, meanwhile, stands apart being a member of the EU under Article 355(3) of the Treaty on the Functioning of the EU. Historically the most important relationship the UKOTs have had is with the United Kingdom (UK) (see Clegg, 2009; Clegg and Gold, 2011; Hintjens and Hodge, 2012), but in recent years links with the EU have grown. The UKOTs benefit from economic and environmental cooperation, as well as development assistance. Beyond the policy benefits, the deepening institutional links between the UKOTs and the EU, particularly via the European Commission, have been supported by the Territories, providing as they do more direct access to EU policy makers. In addition, the growing cooperation between the UKOTs and Dutch, French and Danish territories in the Overseas Countries and Territories Association (OCTA) has brought real gains, including greater political visibility of the territories in Brussels and a higher international profile. Politically, there is also a view that the EU reinforces the self-determination of the UKOTs, particularly where a territory is the subject of a territorial dispute between the UK and other states.

\footnotetext{
* Correspondence Address: Department of Health and Social Sciences, University of the West of England, Frenchay Campus, Coldharbour Lane, Bristol, BS16 1QY, UK. Email: peter.clegg@uwe.ac.uk.
} 
The consequences of the decision by the UK electorate to 'Leave' the EU are still uncertain. No one involved in the forthcoming negotiations has much idea over how long they might take, or how any future relationship between the UK and the EU might be organised. Thus for the UKOTs there are concerns over whether they could lose an important source of political, economic and financial support. In the short-term the Territories will retain their benefits, but must ensure their interests are not neglected or actively marginalised during the period up to the UK's departure. The UKOTs must also prepare for the exit negotiations to come, and agree an effective strategy to influence those talks. Also, the UKOTs must explore and then articulate their preferred future relationship with the EU. This will not be easy as the interests of the Territories are not at all uniform when it comes to the EU. In terms of the outcome of the exit negotiations the UKOTs would benefit most from a deal that keeps the UK, and thus the Territories, closely aligned with the EU. The present benefits will fade away the more detached relations become. Thus the article provides an assessment of both the benefits of the present relationship and the risks and opportunities moving forward as the realities of Brexit crystallise. However, in order to help set the scene the article offers first a short overview of the UKOTs themselves.

\section{The UKOTs}

The Territories can be found in the Caribbean, West Atlantic, South Atlantic, Indian Ocean, Pacific and Europe. The number of inhabitants range from 65,000 in Bermuda to around 40 in Pitcairn. The vast majority of UKOTs are economically self-sufficient and have interests in a range of industries. Bermuda, BVI, and Cayman Islands have sizeable financial centres and are successful tourism destinations; Gibraltar's economy is thriving on the back of an extensive shipping trade, international finance, and an online gaming industry; while the Falkland Islands economy is based on fisheries, tourism, and agriculture. Thus these territories have relatively high GDPs per capita, e.g. Falkland Islands, US\$92,675 and Cayman Islands, US\$59,657. Yet their economic vulnerability is a concern. Other territories are struggling more, particularly Montserrat and Pitcairn, both of which receive budgetary aid from the UK. Further, the Territories are well known for their natural environment and associated biodiversity. They are home to many habitats and species not found anywhere else in the world. Indeed it is estimated that $90 \%$ of the biodiversity within the UK is located in the Territories (FCO, 2012, p. 39).

\section{The Basis of the UKOT-EU relationship}

The UKOTs (apart from Gibraltar) have ties with the EU under the banner of Overseas Countries and Territories (OCTs). The OCTs are not part of the EU and thus are not directly subject to EU law, but they do have associate status - under Part IV of the Treaty. The key articles within Part IV are Articles 198 to 203, which set out the underlying basis of the relationship, focusing on the promotion of economic and social development; the establishment of close economic relations; the importance of non-discrimination in economic matters; and the right to free movement of OCT workers (Official Journal of the EU, 2012).

Links between the UKOTs and the EU were established in 1973 on the UK's accession (to the European Economic Community, EEC), although the OCTs more generally were referenced in the original Treaty of Rome (Treaty Establishing the EEC) in 1957. Until recently agreements between the OCTs and the EU were mainly 'light' versions of the arrangements with the African, Caribbean and Pacific (ACP) group of countries (Hannibal, Holst, Pram Gad, and Adler-Nissen, 2013, p. 80). In addition, the administering powers, rather than the OCTs, 
led negotiations with the EU. However, more recently, the OCTs have gained a stronger voice within the Union. One outcome was a new agreement - Council Decision 2013/755/EU on the Association of the Overseas Countries and Territories with the EU ('Overseas Association Decision', OAD), adopted on 25 November 2013 (Official Journal of the EU, 2013). The agreement aims to modernise the relationship between the OCTs and the EU, 'moving beyond development cooperation and focusing on a reciprocal relationship based on mutual interests' (European Commission, 2016a).

There are also several financial instruments linked to the new OAD. Total EU bilateral funding for the UKOTs via the 11th European Development Fund (EDF, 2014-20) is €76.8 million; a sizable increase on the 10th EDF (€62.7 million). Regional funding has also been raised by $€ 60$ million (European Commission, 2016a). In addition, there is funding from the European Investment Bank and the EU's general budget, e.g. via its horizontal programmes for sectors such as research, the environment, education, and competitiveness.

As mentioned before Gibraltar has a closer relationship than the other UKOTs, being part of the EU since the UK's accession in 1973. Gibraltar's relationship is framed by Article 355(3) of the Treaty of the Functioning of the EU (Official Journal of the EU, 2012, p. 198). Under this status Gibraltar applies most EU laws, with the exception of those that relate to the Common Agricultural Policy, the Value Added Tax (VAT) Area, the EU common customs territory and the EU's Common Commercial Policy. These derogations are covered by Articles 28 and 29 of the UK Act of Accession of 1972 (Official Journal of the European Communities, 1972, p. 20). Further, Gibraltar is not part of the Schengen Area. On the other hand, it benefits from several funding streams, including the European Regional Development Fund (ERDF) and the European Social Fund (ESF).

\section{What are the key aspects of the relationship for the UKOTs?}

As was mentioned in the Introduction the UKOTs benefit in various ways through their links with the EU, both directly and indirectly, and this part of the article considers these in turn; beginning first with trade and trade-related issues.

\section{Trade and Trade-related Issues}

For the UKOTs that are part of the OAD, part three of the Decision considers trade and trade related cooperation. The key provisions focus on free access for OCT goods entering the EU; flexible rules of origin; improving the market access of OCT services and investments; cooperation in the area of financial services; and raising trade capacity in the OCTs (Official Journal of the European Union, 2013). The OAD extended the trade benefits available to OCTs, building on past agreements which had gradually improved their access to the EU market. These changes were also important as they corrected an erosion that had taken place in the competitive position of OCTs vis-à-vis the EU market.

With respect to UKOT exports into the EU market, for Falkland Islands, total sales of locally produced fish, meat, and other agricultural products into the EU are valued at around $£ 180$ million per year, making the EU the largest single market for Falkland Islands' products. It is estimated that over $70 \%$ of the Falkland Islands' GDP is dependent upon access to the European market (Falkland Islands Government, 2016). For Tristan da Cunha the EU market is increasingly important for its high quality and sustainably sourced lobster. After many years of negotiation, the first Tristan da Cunha lobster was imported into the EU in November 2014 (undercurrentnews, 2015).

Cooperation in the area of financial services is another important component of the UKOT-EU trade relationship. First, the EU market is a major one particularly for Bermuda, 
with its focus on insurance and reinsurance, accounting for about $40 \%$ of the European property catastrophe reinsurance market (Reuters, 2012). Bermuda has third country equivalence under Solvency II, the EU's prudential regulatory regime which sets out rules to develop a single market for the insurance sector. It allows third country insurers to operate in the EU without complying with all EU rules (Official Journal of the EU, 2016). Second, the OCTs are able to discuss financial services and tax initiatives with the EU before they are implemented. This is considered a benefit despite the EU having taken steps against so-called tax-havens in the past.

For Gibraltar access to the EU single market is extremely important. Its shipping trade, and its online gaming industry that employs around 3,500 people representing over $18 \%$ of private sector jobs, have grown as a result of this access (Government of Gibraltar, 2016). Also, Gibraltar has sizable interests in investment services, insurance and banking. These industries have been supported by an EU agreement, which allows licensed institutions in Gibraltar to provide services across the EU without having to seek separate authorisation in host member states - so called 'passporting rights'. For instance, there are over 60 insurance companies operating out of the territory that benefit from this privileged access (Government of Gibraltar, 2016). Gibraltar can also offer tariff free access to investors under free movement of capital rules.

\section{Strengthening and Diversifying the UKOT Economies}

The EDF supports macroeconomic stability, facilitating economic diversification, and encouraging the growth of Small and Medium Enterprises (SMEs). For example, under the $10^{\text {th }}$ EDF (2008-13) €11.7 million was allocated to Anguilla to assist the government in implementing its medium-term economic strategy, focussing on improving macroeconomic stability, stimulating sustainable and diversified economic growth, and enhancing social development and social protection (European Commission, 2016b). Also under the 10th EDF Falkland Islands received $€ 4.13$ million as budget support. This fed into 'The Islands Plan, 2014-2018', with the objective of diversifying the economy, particularly in relation to decreasing reliance on the fisheries industry (Falkland Islands Government, 2014). In Tristan da Cunha meanwhile EU funding has supported new water and electrical networks, and some small harbour repairs, and in Pitcairn the EU is funding two related infrastructure projects: the building of a jetty at Tedside, on the North Western side of the Island, and upgrading the road linking Tedside to Adamstown (the capital). It is hoped that this will improve accessibility for cruise ship visitors and boost the island's frail economy. In terms of regional funds, again under the 10th EDF, the 'Strengthening the Development of Small and Medium Enterprises of the Overseas Countries and Territories in the Caribbean Region' programme managed by BVI as Deputy Regional Authorising Officer is a notable example (Government of the BVI, 2012).

Gibraltar, also benefits from EU funds that support its economy. In particular, funding from the ERDF has been important, and at present Gibraltar is in receipt of funds from the Growth and Jobs Goal Programme, 2014-2020 (ERDF, n.d.). Approximately €5.5 million has been allocated to aid sustainable economic growth, competitiveness, employment, encourage enterprise, and promote a knowledge based society. This programme is being supplemented by resources from the ESF, with initiatives fostering sustainable and quality employment, labour mobility, and education and vocational training for skills and lifelong learning (Government of Gibraltar, n.d.). A range of businesses have been strengthened as a consequence of EU funding, including those involved in freight forwarding, light industrial activity, eco-tourism, broadband services, and medical and health services. Government records show that 3,615 jobs have been created or safeguarded as a result of EU-funded projects; there have also been over 5,000 qualifications gained (MercoPress, 2016). 
Part Two of the OAD focuses on sustainable development, and Chapter 1 considers 'Environmental Issues, climate change, and disaster risk reduction' (Official Journal of the EU, 2013). The Decision details a number of priorities, including: ensuring the conservation, restoration and sustainable use of biological (including marine) diversity; assisting the adaptation and mitigation of climate change in the OCTs, supporting the OCTs in becoming less dependent on fossil fuels, and helping the OCTs to reduce their vulnerability to natural disasters. There are a wide range of programmes and initiatives in place to help meet these priorities. They include the BEST (Biodiversity and Ecosystem Services in Territories of European overseas) scheme that supports the conservation of biodiversity and sustainable use of ecosystem services including ecosystem-based approaches to climate change adaptation and mitigation (European Commission, n.d.). Funding is also available under the EDF. So for example, a regional envelope for the Caribbean OCTs under the 11th EDF has been agreed, which foresees $€ 40$ million for sustainable energy and marine biodiversity cooperation.

Gibraltar, meanwhile, benefits from funds from the ERDF. One aim for the 2014-2020 programme is to 'assist in sustainable growth in a low-carbon economy' (Ramboll, 2014, p. 13). In particular, there is a focus on supporting the production of renewal energies. Grants are being provided for micro-renewable energy projects (Ramboll, 2014, p. 14). EU funds have also been given for a range of other projects, such as the building of Commonwealth Park, Gibraltar's first green zone. A raft of European environmental regulation also applies to Gibraltar, including the Habitats Directive and Birds Directive, which are the key instruments for the designation of protected areas within the EU (Official Journal of the European Communities, 1992; Official Journal of the EU, 2010).

\section{Maintaining Security}

The most important issue in regard to security relates to the respective territorial claims against Falkland Islands and Gibraltar. The Falklands believes that the UK's membership of the EU and provisions in the Treaty of Rome and its successors offer the UK and Falkland governments 'considerable certainty and support from EU member states' (Falkland Islands Government, 2016). Specifically the Treaties list the OCTs (see Annex II of the Treaty on the Functioning of the EU), thus recognising the status of the Falklands Islands as a UKOT. All Member State signatories of the Treaty are committed in their support of this position. Falkland Islands considers that this is an important extra buffer against Argentina's claim, and that without it Argentina could well take a more aggressive political stance in challenging the status of the Falklands as a UKOT. Gibraltar benefits similarly in regard to Spain. In addition, it has adopted EU justice and home affairs legislation, which facilitates cooperation with other European countries, including Spain, on judicial and police matters (Government of Gibraltar, 2016b).

\section{Free Movement of People}

Free movement within the EU for UKOT citizens with UK nationality is defined within Article 20 of the Treaty on the Functioning of the EU. Article 20(1) states that 'Every person holding the nationality of a Member State shall be a citizen of the Union, and Article 20(2) continues that 'Citizens of the Union shall enjoy the rights and be subject to the duties provided for in the Treaties'. The citizenship rights are summarised in Article 20(2) and set out in detail in Articles 21 to 24 of the Treaty. These include 'Every citizen of the Union shall have the right to move and reside freely within the territory of the Member States' (Official Journal of the EU, 2012, pp. 56-58). Free movement to travel, work and reside in the EU is an important benefit for the 
UKOTs, most of whose residents are UK citizens. This is particularly crucial for Gibraltar with its difficult relationship with Spain. Ten thousand Spanish citizens cross the border every day to work in Gibraltar, while almost 10 million visitors enter the territory via Spain each year (Government of Gibraltar, 2016a). Without EU rules on free movement and EU monitoring of the border, Spain could well make it much more difficult for people (and goods) to cross.

A further issue relates to the fact that some residents of the UKOTs do not have UK citizenship but British Overseas Territories Citizenship, which does not grant the right of abode in the UK. In turn people with the latter citizenship do not benefit from the right of free movement as defined by Article 20 of the EU treaty, and as a consequence were not allowed until recently to travel freely across the EU Schengen Area. However, in June 2014 under an agreement negotiated by the UK and EU all British Overseas Territories citizens are permitted to travel visa free to the EU Schengen Area for a maximum of 90 days (FCO, 2014).

\section{Political Visibility of the UKOTs in Europe}

Beyond the sectoral specific support which the UKOTs receive from the EU, they also benefit from the institutional links that exist. The principal link is with the European Commission, via its Directorate-General for International Cooperation and Development (DEVCO) and its OCT Unit (DEVCO Unit 0.7). Stemming from this link there are various associated groupings to facilitate cooperation. The OCT-EU Forum brings together OCT governments (including the UKOTs), the European Commission and representatives of the Member States. At the last Forum in February 2016, a range of issues were discussed including, climate change, sustainable energy, implementation of 11 th EDF programming, and the promotion of research, education and innovation. Tripartite meetings are also held between the Commission, the OCTs and the Member States to which they are linked. Partnership Working Parties are the third form of policy dialogue. These act in an advisory capacity and provide a framework for technical discussions on particular areas of policy. Contacts with the other institutions are less developed, but the Territories have good connections with 20 or so Members of the European Parliament (MEPs). Finally, there is OCTA, which was created in 2002 to bolster the level of cooperation amongst the OCTs. Among other things, OCTA directly engages the European Commission and European Parliament on behalf of the 22 OCTs listed in the OAD.

Gibraltar, once again, stands somewhat apart. It has broader ties with the European Commission as its interests are not represented by DEVCO Unit 0.7. Gibraltar is also not a member of OCTA, but it does have formal representation in the European Parliament. Since 2004 Gibraltar has taken part in elections to the parliament as part of the combined South West region of the UK.

\section{UKOTs and the Referendum}

During the campaign leading up to the referendum the UKOTs, perhaps unsurprisingly, did not receive much attention. What coverage there was focused largely on Gibraltar and the Falkland Islands and the risks posed to their security and economic wellbeing if the UK left the EU. One high profile article was written by the former Conservative Foreign Secretary William Hague (Hague, 2016). Both Gibraltar and Falkland Islands are close to many Britons' hearts due to the particular challenges that face them, and the 'Remain' camp hoped that the EU's role in supporting the territories would resonate with some voters. The wider possible impacts of Brexit for the UKOTs were barely considered. In terms of the UKOT governments, Gibraltar was particularly forthright in their support for the UK to remain in the EU (Government of 
Gibraltar, 2016a; 2016b). Other governments were more circumspect, as their populations were not able to vote in the referendum.

However, the arguments of the 'Remainers' were challenged by much of the right-wing media (e.g. The Telegraph, 2016) and by many Conservative Ministers and MPs. For instance, James Duddridge, the Minister in the Foreign and Commonwealth Office (FCO) responsible for the UKOTs was in the 'Leave' camp. He argued that, 'An independent Britain can spend more time developing our historic ties rather than be shackled by the regulation and political infrastructure that is a federal union. OTs value the relationship with the UK more than the EU. The EU is sucking the life out of the UK as an independent nation state' (Caribbean Insight, 2016 , p. 4). When the vote was held on 23 June 2016 the UK voted to 'Leave' the EU with $52 \%$ supporting that choice and $48 \%$ voting to 'Remain'. In Gibraltar, however, there was a very clear vote to 'Remain' by 19,322 to 823 . But as Gibraltar's chief minister, Fabian Picardo, said, the territories votes 'did not even move the needle' (The Economist, 2016).

\section{Prospects for Continued Cooperation after Brexit}

In the short-term nothing much will change. The existing trade relationships will continue, so too the provisions for the free movement of people. Further, the institutional links the UKOTs have with the European Commission and European Parliament will remain in place. In relation to EU funding this will be maintained up until 2020 unless the UK reneges on its contributions. However, it is important that the disbursement of funds should be agreed as soon as possible, so the planned projects are finalised and can proceed. Even in the longer-term present aspects of the relationship will be preserved, for example Bermuda will likely keep its key role in the EU's insurance and reinsurance market via its third country access. However, for most UKOTs and in most sectors the impacts will be sizeable, particularly as the new Prime Minister Theresa May has said that exit from the EU means exit. However, what comes after remains uncertain, and so the final part of the article offers several tentative suggestions on how the wide-ranging interests of the UKOTs can best be secured.

\section{Trade}

In relation to trade, the UKOTs will retain free access to the EU market, and this will help certain industries, for instance Gibraltar's insurance and online-betting business; $90 \%$ of which is focused on the UK (The Economist, 2010). However, as was shown earlier all UKOTs have much to lose if the EU-27 market is shut. So what options might be available to the UK which would best facilitate UKOT-access? At present there is no consensus, but various alternatives may be on offer, including the Norway model, a bilateral trade deal that is preferred by Switzerland and Canada, or the World Trade Organisation (WTO) model (Dhingra and Sampson, 2016). The Norway model would be the one that most closely aligns to the existing UK-EU relationship, while the WTO option would be a major departure meaning higher tariffs on UK goods entering the EU and more restrictions on its services sector. For the UKOTs, the closer the relationship the UK has with the EU, the better it will be for them. So a deal similar to the one that Norway has would probably be the most favoured. On the back of that the UKOTs would be in a good position to gain access to the single market for both goods and services, and benefit from free movement within the EU, possibly within the context of a reimagined OAD, which would allow the UKOTs to maintain many of their present benefits. However, the option might not be acceptable to the UK, but the trade interests of the UKOTs must be acknowledged. As Gibraltar's chief minister has argued recently 'a hard Brexit would be really an existential threat to [our] economic model' (The Independent, 2016a). 
If a looser trading agreement is finalised between the UK and the EU, the UKOTs might have to look elsewhere for opportunities to maintain ties with the EU. Gibraltar is exploring the 'reverse Greenland' idea. In 1985 Greenland left the EU without breaking its political links with Denmark. For Gibraltar the suggestion is that it would remain in the EU, while continuing to be a UKOT (The Independent, 2016a). For many of the other UKOTs one option would be to align themselves with the African, Caribbean and Pacific (ACP) group of states, and join their Economic Partnership Agreements (EPAs) with the EU. EPAs offer free access, with certain exceptions, to ACP goods and services into the EU market. Further, some ACP SMEs are afforded special protections, and the EPAs include provisions for short-term visitors for business purposes. Finally, the EU offers financial support to ACP countries via the EDF, which of course also supports presently many UKOTs.

So in some respects the EPAs offer a positive model for many, but crucially not for all, UKOTs. However, there are drawbacks, which may well be insurmountable. First, the EPAs involve independent states, and thus the underlying framework of the agreements would have to be altered to include the UKOTs. Second, EU and ACP states would have to agree to the UKOTs inclusion, and with a detached UK this may well be difficult to achieve. Third, the UKOTs would lose their distinctive position and be amalgamated within the much larger ACP group. Fourth, the free movement of ACP citizens within the EU is not permitted, and this would be a significant loss for the UKOTs, unless special arrangements could be agreed.

\section{Access to EU funding}

As with trade, the nature of any future UK relationship with the EU is going to have an impact on the likelihood of continued EU aid to the UKOTs. A closer relationship may well offer the opportunity of some EU funds being given to the UKOTs. A key part of any consideration of this issue relates to the nature of the EDF. The EDF has a special status and is managed outside of the EU's general budget. Contributions are made directly by EU member states, and funding can also be provided by third countries (Official Journal of the EU, 2015). Consequently, there may be flexibility here for the UK to provide funds and for the UKOTs, or potentially via the ACP. For Gibraltar, which does not benefit from the EDF, the scenario is similar. Continued EU funding will depend on a close future relationship between the UK and the EU.

If EU funding is lost, however, will the UK be able to make-up any short-falls in funding? Claims were made by the 'Leave' camp in the lead up to the referendum about how much money would become available if the UK left. Many of these promises have already unravelled, but there will be demands from government departments, local authorities, businesses and key services such as the National Health Service (NHS) for extra money to plug the gap caused by the withdrawal of EU funds. In such circumstances the UKOTs voice may struggle to be heard. The fact that the UKOTs do have 'first call' on the UK's aid budget might help, but there is no certainty that additional funding will come. Also, the relative wealth of the UKOTs means that the UK government and the British public will require some convincing that the Territories require additional funding.

\section{Free movement of people}

As noted previously, the free movement to travel, work and reside in the EU are important benefits for the UKOTs, most of whose residents are UK citizens. For Gibraltar, free movement is particularly crucial, and it is expected that some kind of deal will be reached between the UK and the EU, from which Gibraltar will benefit. Indeed Spain, despite its rhetoric, would likely welcome a deal as the neighbouring Spanish area of Campo de Gibraltar gains much from its links with Gibraltar (The Economist, 2016). For UK citizens in the other UKOTs there 
is good chance that free movement will be maintained for them, but the position of British Overseas Territories Citizens must not be neglected. Every effort should be made to preserve their existing level of entry.

\section{Security}

Argentina has stated that Brexit would not do much to enhance its claim over the Falkland Islands. However, Spain has been more bullish. Following the referendum Spain's foreign minister Jose Manuel Garcia-Margallo stated that '[Brexit is] a complete change of outlook that opens up new possibilities on Gibraltar not seen for a very long time. I hope the formula of co-sovereignty - to be clear, the Spanish flag on the Rock - is much closer than before' (Reuters, 2016). Both Gibraltar and UK strongly oppose such an option and change will not come for the foreseeable future, but Brexit may well make the UK, Gibraltar and Falkland Islands more exposed diplomatically going forward.

\section{How best to defend the UKOTs' interests}

The situation is very uncertain and as a result it makes it very difficult for the UKOTs to plan their response. However, due to the level of uncertainty and the present lack of capacity on the part of the UK to undertake the negotiations and make the necessary changes to secure Brexit, there is an opening for the Territories to be pro-active and influence the debate. In addition, the UK government has made clear that the UKOTs will be involved in the negotiations, although the extent of this involvement remains unclear (The Independent, 2016b). To influence the debate effectively the UKOTs can engage with the negotiating machinery that is being created to secure the UK's withdrawal from the EU; via government departments; via the annual Overseas Territories/UK Joint Ministerial Council; and via Parliament. Lobbying might also be possible in Brussels and key capitals of EU member states. Lobbying will not be easy and must be undertaken in a sensitive way due to the distinct status of the UKOTs, which affords them a limited role in foreign affairs. In terms of strategy, the UKOTs should formulate a collective response, whilst also promoting their individual interests. They should work, where possible, with other stakeholders, such as the Crown Dependencies and UK local authorities; also they may well be able to join together with private sector and civil society groups based in the Territories.

\section{Conclusion}

The uncertainty caused by the vote to leave the EU has been seen most clearly in the UK itself. However, the impacts will be felt far and wide, including in the UKOTs. Although bar Gibraltar their citizens were not able to vote, the likely consequences of Brexit for the Territories will be significant. Much will depend on the position of the UK government in moving forward. The closer the relationship the $\mathrm{UK}$ is able or wants to maintain with the EU, the better it will be for the UKOTs. Much of what the UK will negotiate will then be applied to the UKOTs. Saying that however the Territories have an important role to play in safeguarding their interests. If the Territories are able to promote a positive and realistic agenda then they will have a good chance of securing a link with the EU, which they value highly. 


\section{Acknowledgement}

The author would like to thank the United Kingdom Overseas Territories Association (UKOTA) for its support during the preparation of this article.

\section{References}

Caribbean Insight (2016) The Overseas Territories Impacted, 39(123), p.4

Clegg, P. (2009) Governing the UK Caribbean Overseas Territories: A Two-Way Perspective, in Clegg, P. and Pantojas-Garcia, E. (Eds) Governance in the Non-Independent Caribbean: Challenges and Opportunities in the Twenty-First Century, Kingston, Jamaica: Ian Randle Publishers.

Clegg, P. and Gold, P. (2011) The UK Overseas Territories: A decade of progress and prosperity?, Commonwealth and Comparative Politics, 49(1), pp. 115-135.

Dhingra, S. and Sampson, T. (2016) Life after BREXIT: What are the UK's options outside the European Union? Centre for Economic Performance, London School of Economics, http://cep.lse.ac.uk/pubs/download/brexit01.pdf, accessed 16 August 2016.

European Commission (2016a) International Cooperation and Development: OCT-EU relations in detail, https://ec.europa.eu/europeaid/where/octs_and_greenland/index_en.htm_en, accessed 10 August 2016.

European Commission (2016b) International Cooperation and Development: Anguilla, http://ec.europa.eu/europeaid/countries/anguilla_en, accessed 10 August 2016.

$\begin{array}{lllll}\text { European } & \text { Commission } & \text { (n.d.) } & \text { Environment }\end{array}$ http://ec.europa.eu/environment/nature/biodiversity/best/index_en.htm, accessed 17 August 2016.

European Regional Development Fund (n.d.) Gibraltar European Regional Development Fund Investment for Growth and Jobs Goal 2014-2020: Communication Strategy, http://www.eufunding.gi/docs/20142020\%20ERDF\%20Communication\%20Strategy.pdf, accessed 15 August 2016.

Falkland Islands Government (2014) The Islands Plan, 2014-18, http://www.falklands.gov.fk/self-sufficiency/theislands-plan/, accessed 5 July 2016.

Falkland Islands Government (2016) Written evidence provided by Falkland Islands Government to the House of Commons Foreign Affairs Committee: Implications of the referendum on EU membership for the UK's role in the world,

February,

http://data.parliament.uk/WrittenEvidence/CommitteeEvidence.svc/EvidenceDocument/Foreign\%20Affairs/The $\% 20$ costs $\% 20$ and $\% 20$ benefits $\% 20$ of $\% 20 U K \% 20$ membership $\% 20$ of $\% 20$ the $\% 20 \mathrm{EU} /$ written $/ 29430 . h$ tml, accessed 29 June 2016.

Foreign and Commonwealth Office (2012) The overseas territories: Security, success and sustainability. Cm 8374, June. London: The Stationary Office.

Foreign and Commonwealth Office (2014) Visa free access to EU Schengen area, 23 June, https://www.gov.uk/government/news/visa-free-access-to-eu-schengen-area, accessed 20 June 2016.

Government of the British Virgin Islands (2012) BVI Signs Financing Agreement for EU Small Business Project, 28 September, http://www.bvi.org.uk/government/pressrelease/smeprojectocteusigning, accessed 21 August 2016.

Government of Gibraltar (2016a) Written Evidence to the House of Commons Foreign Affairs Committee: The Potential Effects on Gibraltar Should the United Kingdom Leave the European Union, January, http://data.parliament.uk/WrittenEvidence/CommitteeEvidence.svc/EvidenceDocument/Foreign\%20Affairs/The $\% 20$ costs $\% 20$ and $\% 20$ benefits $\% 20$ of $\% 20$ UK\%20membership $\% 20$ of $\% 20$ the $\% 20$ EU/written/27317.html, accessed 16 August 2016. 
Government of Gibraltar (2016b) Submission to the Foreign Affairs Committee of the House of Commons on the position of Gibraltar in the European Union and the challenges posed were that position to change after the Referendum of 23 June on whether the UK and Gibraltar should remain in the EU or should leave, March, http://data.parliament.uk/WrittenEvidence/CommitteeEvidence.svc/EvidenceDocument/Foreign\%20Affairs/The $\% 20$ costs $\% 20$ and $\% 20$ benefits $\% 20$ of $\% 20$ UK $\% 20$ membership $\% 20$ of $\% 20$ the $\% 20$ EU/written $/ 30556 . h t m l$, accessed 16 August 2016.

Government of Gibraltar (n.d.) ESF Operational Programme 2014-20, http://www.eufunding.gi/newsletters/ESF\%20OP\%202014\%202020\%20\%2002-03\%20FINAL.pdf, accessed 18 August 2016.

Hague, W. (2016) Leaving the EU would be disastrous for the Falklands, Gibraltar and Ulster, The Telegraph, 11 May, http://www.telegraph.co.uk/news/2016/05/09/leaving-the-eu-would-be-disastrous-for-the-falklandsgibraltar-a/, accessed 22 August 2016.

Hannibal, I., Holst, K., Pram Gad, U., and Adler-Nissen, R. (2013) European Union: facilitating the OCTs in Brussels, in Adler-Nissen, R. and Pram Gad, U. (Eds) European Integration and Postcolonial Sovereignty Games: The EU Overseas Countries and Territories, Abingdon: Routledge.

Hintjens, H. and Hodge, D. (2012) The UK Caribbean Overseas Territories: governing unruliness amidst the extraterritorial EU, Commonwealth and Comparative Politics, 50(2), pp. 190-225.

MercoPress (2016) Gibraltar has benefited from $60 \mathrm{~m}$ Euros in EU funding, 23 May, http://en.mercopress.com/2016/05/23/gibraltar-has-benefited-from-60m-euros-in-eu-funding, accessed 15 August 2016.

Official Journal of the European Communities (1972) Documents concerning the accession to the European Communities of the Kingdom of Denmark, Ireland, the Kingdom of Norway and the United Kingdom of Great Britain and Northern Ireland, 27 March, http://eur-lex.europa.eu/legalcontent/EN/TXT/PDF/?uri=OJ:L:1972:073:FULL\&from=EN, accessed 15 August 2016.

Official Journal of the European Communities (1992) Council Directive 92/43/EEC of 21 May 1992 on the conservation of natural habitats and of wild fauna and flora, http://eur-lex.europa.eu/legalcontent/EN/TXT/PDF/?uri=CELEX:31992L0043\&from=EN, accessed 20 August 2016.

Official Journal of the European Union (2010) Directive 2009/147/EC of the European Parliament and of the Council of 30 November 2009 on the conservation of wild birds, http://eur-lex.europa.eu/legalcontent/EN/TXT/PDF/?uri=CELEX:32009L0147\&from=EN, accessed 20 August 2016.

Official Journal of the European Union (2012) Treaty on the Functioning of the European Union, C 326/47, http://eur-lex.europa.eu/legal-content/EN/TXT/?uri=CELEX:12012E/TXT, accessed 8 August 2016.

Official Journal of the European Union (2013) Council Decision 2013/755/EU of 25 November 2013 on the association of the overseas countries and territories with the European Union (Overseas Association Decision), L 344/1, http://www.octassociation.org/IMG/pdf/oj_jol_2013_344_r_0001_01_en_txt.pdf, accessed 8 August 2016.

Official Journal of the European Union (2015) Council Regulation (EU) 2015/323 of 2 March 2015 on the financial regulation applicable to the 11th European Development Fund, http://eur-lex.europa.eu/legalcontent/EN/TXT/PDF/?uri=CELEX:32015R0323\&from=EN, accessed 18 July 2016.

Official Journal of the European Union (2016) Commission Delegated Decision (EU) 2016/309 of 26 November 2015 on the equivalence of the supervisory regime for insurance and reinsurance undertakings in force in Bermuda to the regime laid down in Directive 2009/138/EC of the European Parliament and of the Council and amending Commission Delegated Decision (EU) 2015/2290, http://eur-lex.europa.eu/legalcontent/EN/TXT/PDF/?uri=CELEX:32016D0309\&from=EN, accessed 8 August 2016.

Ramboll (2014) Gibraltar ERDF Operational Programme 2014-2020: Strategic Environmental Assessment Environmental Report, December, http://www.eufunding.gi/docs/Environmental\%20Report.pdf, accessed 20 August 2016. 
Reuters (2012) Bermuda on track to comply with EU insurer rules, 26 June, http://uk.reuters.com/article/insurance-bermuda-idUKL6E8HQ5UT20120626, accessed 2 August 2016.

Reuters (2016) Spain seeks to jointly govern Gibraltar after Brexit, 24 June, http://uk.reuters.com/article/ukbritain-eu-gibraltar-idUKKCN0ZA169, accessed 20 August 2016.

The Economist (2016) Spain, Gibraltar and Brexit: Rock out, 16 July, http://www.economist.com/news/europe/21702147-territory-dragged-europe-against-its-will-spain-looms-rockout, accessed 15 August 2016.

The Independent (2016a) Gibraltar faces 'existential threat' to its economy if there's a 'hard Brexit' deal, its chief minister warns, 20 August, http:/www.independent.co.uk/news/uk/gibraltar-existential-threat-economy-hardbrexit-deal-eu-fabian-picardo-a7201211.html, accessed 21 August 2016.

The Independent (2016b) David Cameron's statement to Parliament on Brexit - full text, 27 June: http://www.independent.co.uk/news/uk/politics/david-cameron-statement-to-parliament-brexit-full-texta7106211.html, accessed 30 June 2016.

The Telegraph (2016) The Falklands would be safer after Brexit, 11 May, http://www.telegraph.co.uk/news/2016/05/11/the-falklands-would-be-safer-after-brexit/, accessed 22 August 2016.

Undercurrentnews (2015) MSC lobster from world's most remote community launches in top London department store, 17 February, https://www.undercurrentnews.com/2015/02/17/msc-lobster-from-worlds-most-remotecommunity-launches-in-top-london-department-store/, accessed 20 August 2016. 